\title{
MEDIA PEMBELAJARAN IPS BERBASIS E-LEARNING
}

\author{
Fahriannor \\ Program Studi Pendidikan Sejarah Fakultas Keguruan dan Ilmu Pendidikan \\ Universitas Lambung Mangkurat \\ Banjarmasin
}

\section{PENDAHULUAN}

Pertumbuhan teknologi informasi sangat berpengaruh terhadap kegiatan manusia. Dimasa saat ini teknologi informasi merupakan fasilitas utama bagi kegiatan di berbagai sektor dalam kehidupan dikarenakan berperan besar atas perubahan yang mendasar pada struktur operasi dan manajemen organisasi, pendidikan, transportasi, kesehatan serta penelitian (Anshori, 2017).

Keberhasilan pembelajaran yang dilaksanakan dalam satu kegiatan pendidikan merupakan bagaimana siswa dapat belajar, dengan cara mengidentifikasi, mengembangkan, mengorganisasi, dan menggunakan segala macam media serta sumber belajar. Pendidikan merupakan membelajarkan peserta didik dari tidak tahu menjadi tahu, dari tidak mampu menjadi mampu, dan dari tidak mau menjadi mau. Pembelajaran diarahkan pada penghargaan dari keterampilan berpikir dan sikap sebagai hasi belajar bukan hanya kemampuan kognitif rendah (Putro, 2013). Dengan demikian upaya pemecahan masalah dalam pendekatan teknologi informasi dan komunikasi dalam pendidikan adalah dengan mendayagunakan sumber dan media belajar. Definisi teknologi pembelajaran menyatakan bahwa teknologi pendidikan merupakan teori serta praktek dalam hal desain, dan pengembangan. Hal ini ditandai dengan pengubahan istilah dari teknologi pendidikan menjadi teknologi pembelajaran.

Pembelajaran IPS perlu dilakukan rekonstruksi, pembelajaran IPS harus dapat mempersiapkan peserta didik sesuai dengan kebutuhan peserta didik pada era kekinian sejalan dengan tuntutan pertumbuhan yang terjadi pada era informasi dan pertumbuhan iptek. Pergerakan aktivitas kehidupan manusia semakin cepat dan tiada batas (Putro, 2013).

Sistem pembelajaran berbasis e-learning yang diterapkan dalam pembelajaran IPS merupakan menggunakan multimedia center sehingga contoh penerapan ilmu pengetahuan sosial serta juga kajian materi IPS lain yang diperlukan dapat dipeoleh dengan mudah melalui web serta siswa akan lebih tertarik karena menerapkan sistem pembelajaran secara online (Ashfia, \& Puspitaningrum, 2018). 
Media teknologi informasi sekarang ini tidak dapat dielakkan dari berbagai sisi kehidupan manusia. Kalangan generasi muda ialah kelompok umur yang sangat mudah menyerap pertumbuhan teknologi ini. Dilihat kegiatan sehari-harinya di tangan mereka hampir tidak dapat dilepaskan dari laptop/notebook, handphone/smartphone sampai gadget /tablet (Wijaya, \& Tastra, 2014). Demikian juga dengan media yang dapat diakses, canggihnya teknologi yang ada di tangan mereka seakan dunia ada di genggaman tangan baik di jenjang SD, SMP, SMA/SMK bahkan Perguruan Tinggi. Melalui ujung jarinya mereka dapat mengakses informasi yang diinginkan. Rosenberg (2001) dalam Yazdi (2012) mengemukakan bahwa e-learning merujuk pada penggunaan teknologi internet untuk mengirimkan serangkaian solusi yang dapat meningkatkan pengetahuan dan keterampilan. 


\section{PEMBAHASAN}

E-learning merupakan proses pembelajaran yang dituangkan melalui teknologi internet. Di samping itu prinsip sederhana, personal, dan cepat perlu dipertimbangkan. Untuk menambah daya tarik dapat pula menggunakan teori games. Oleh karena itu prinsip dan komunikasi pembelajaran perlu di desain seperti layaknya pembelajaran konvensional. Di sini perlunya pengembangan model e-learning yang tepat sesuai dengan kebutuhan (Yazdi, 2012).

E-Learning ialah sebuah inovasi yang mempunyai kontribusi sangat besar terhadap perubahan proses pembelajaran, dimana proses belajar tidak lagi hanya mendengarkan uraian materi dari guru tetapi peserta didik juga melakukan aktivitas lain seperti mengamati, melakukan, mendemonstrasikan dan lain-lain. Materi bahan ajar dalam aplikasi E-Learning ini dapat divisualisasikan dalam berbagai format serta bentuk yang lebih dinamis dan interaktif sehingga peserta didik akan termotivasi untuk terlibat lebih jauh dalam proses pembelajaran tersebut.

Menjawab tantangan pendidikan 4.0 berbagai inovasi dilakukan dalam proses pembelajaran ini, menerapkan adanya metode pembelajaran dengan cara E-Learning dengan menggunakan aplikasi didalam pembelajaran IPS. Satu satunya ialah pengembangan dan pengaplikasikan pembelajaran berbasis elektronik (electronic learning) yang memanfaatkan komputer dan jaringan internet untuk proses pembelajaran. Inovasi ini dilakukan karena perkembangan ilmu pengetahuan dan teknologi yang sangat cepat dan juga fasiltas serta siswa yang memadai adanya penggunaan aplikasi E-Learning ini (Ashfia, \& Puspitaningrum, 2018). Bagi siswa, penerapan e-learning ini memberikan pengalaman belajar baru tentang proses pembelajaran yang tidak melulu bersifat konvensional di kelas dan mempermudah proses pembelajaran, baikmenyangkut aktivitas pembelajaran, ketersediaan bahan ajar, penyelesaian tugas-tugas kurikuler, dan evaluasi.

Pembelajaran yang terjadi melalui media E-Learning ini menjadikan peserta didik untuk berfikir secara luas. Di sini para peserta didik dapat secara langsung berada dalam rangakaian proses mencari, memperhatikan, mendapatkan, memahami, dan menggunakan informasi. Mereka dapat mengasimilasikan dan memaksimalkan pengetahuan sebelumnya dengan pengetahuan baru yang didapatkan. Proses ini akan membuat pengetahuan dan pemahaman peserta didik semakin berkembang dan semakin terasah lagi. 
Metode pembelajaran dengan menggunakan media E-Learning dalam pembelajaran IPS untuk meningkatkan kemampuan kognitif. Pembelajaran ini dilakukan di semua mata pelajaran tertentu salah satunya adalah pembelajaran IPS. Kemampuan kognitif peserta didik mengalami peningkatan dibandingkan kemampuan kognitif peserta didik tanpa dengan menggunakan media pembelajaran E-Learning.

\section{KESIMPULAN}

Pembelajaran berbasis apikasi e-leaning ini sangat diperlukan peserta didik karena dengan adanya pembelajaran yang mutakhir dan interaktif ini membuat siswa lebih kritis serta aktif.

Pembelajaran berbasis aplikasi e-learning ternyata dapat memberi dampak yang baik bagi hasil belajar peserta didik 


\section{Referensi}

Ashfia, N. A., \& Puspitaningrum, D. A. (2018). PENGGUNAAN APLIKASI (ELEARNING) DALAM PROSES PEMBELAJARAN IPS DI SDN DABASAH I BONDOWOSO. FKIP e-PROCEEDING, 135-146.

Anshori, S. (2017). Pemanfaatan TIK sebagai sumber dan media pembelajaran di sekolah. Civic-Culture: Jurnal Ilmu Pendidikan PKn dan Sosial Budaya, 1(1).

Putro, H. P. N. (2013). Pengembangan Pembelajaran IPS dalam Kurikulum 2013. Mewacanakan Pendidikan IPS, 39.

Wijaya, G. A., Pudjawan, K., \& Tastra, I. D. K. (2014). Pengembangan Media eLearning Berbasis Facebook Pada Pembelajaran IPS Kelas VIII Di SMP Negeri 1 Singaraja. Jurnal Edutech Undiksha, 2(1).

Yazdi, M. (2012). E-learning sebagai media pembelajaran interaktif berbasis teknologi informasi. Jurnal ilmiah foristek, 2(1). 